\title{
Compensation, Competency and Motivation as Determiners of The Performance of Financial Administrative Officers
}

\section{Arief Purwanto \\ Postgraduate of Widyagama University of Malang, Indonesia \\ ariefpurwanto@widyagama.ac.id}

\section{Nirma}

Postgraduate of Widyagama University of Malang, Indonesia

\section{Nasharuddin Mas}

Faculty of Economic and

Business, Widyagama University,

Malang, Indonesia

\begin{abstract}
This study explains the effect of compensation, competency, and motivation on employee performance directly and indirectly. The method used is quantitative - explanatory. The sample is 33 Financial Administration Officers (PPK) in Pasuruan City. Data analysis using SEM-PLS. The results showed that compensation can increase motivation. However, it has not been able to improve performance. Furthermore, competence can increase motivation and be able to improve performance. On the other hand, motivation can improve performance. Other results, indirectly it is known that motivation has not been able to mediate the relationship between compensation and performance. In addition, motivation is able to mediate the relationship between competence and performance
\end{abstract}

Keywords: Compensation, Competency, Motivation

\section{INTRODUCTION}

Financial reports have a very important function, according toPSAK No.1 (2015) function Financial reports provide information about the financial position, financial performance and cash flow of the entity that is useful for most users of the report in making economic decisions. So important is the function of financial reports, therefore both private companies and government institutions oblige the preparation of financial reports every year (Sadeli, 2002). In government institutions, both central and local governments, are required to compile and report their Financial Statements every year. As for the rules that bind government agencies, both the central government and local governments, to compile and report financial reports each year are regulated in Government Regulation Number 8 of 2006 which is outlined in depth in 38 articles.

Regional financial reports are compiled from the consolidated results of SKPD (Regional Public Service Unit) financial reports and BLUD (Regional Public Service Agency) financial reports. In the Pasuruan City Government, regional financial reports are 
prepared by the Financial and Asset Management Agency (BPKA) in the accounting subsector, while in the preparation of financial reports, SKPD and BLUD in each institution are prepared by PPK (Financial Administration Officer) in each SKPD. The preparation of regional financial reports is strongly influenced by the preparation of SKPD financial reports carried out by PPK (Financial Administration Officials). One of the determinants of performance is compensation, compensation is something someone will get when doing a business or job. Compensation is an important factor that can affect individual performance.

The preparation of financial statements is always done every year but in fact there are still many the auditor team of the Audit Board (BPK) findings every year. The data on the number of journals of BPK findings that must be followed up are the findings BPK, where the findings of the journal need to be followed up. In 2017 there was an increase in the number of findings from 40 journals Proposed Adjustment Journal Entry and 5 journals Proposed Reclassification in 2018 to 45 journals Proposed Adjustment Journal Entry and 15 Journal Proposed Reclassification while in 2019 there was a decrease in the findings of journals namely 37 journals Proposed Adjustment Journal Entry and 4 journal Proposed Reclassification. Although the preparation of regional financial statements is done every year, they are still any mistakes. From the above reality shows that the performance of PPK (Office of Financial Management) is still not maximal. The gap phenomenon is closely related to the variables of compensation, competence and motivation to the performance of the Financial Management Officer (PPK) in completing financial statements.

Simamora (2004) defines: Compensation includes financial rewards and intangible services as well as benefits received by employees as part of the employment relationship. Compensation is what employees receive in exchange for their contribution to the organization ". With compensation that is large or at least proportional to the effort issued, it is hoped that it can encourage Financial Administration Officers (PPK) to complete SKPD financial reports accurately and on time considering that in the 2019 fiscal year there is additional compensation received by Financial Administration Officials (PPK) through other objective considerations on the employee's Additional Income component. With this additional compensation, it is hoped that it can improve the performance of the Financial Administration Officer (PPK) in completing the SKPD financial report that is their job. Research on compensation that affects performance is in accordance with the research Meutia et al. (2016) where compensation has a significant effect on performance as well as research results Prianto (2016) which examines the effect of transformational leadership style and compensation on employee performance with motivation as an intervening variable, from the results of this study it is concluded that compensation has a significant effect on performance. Andriana (2017) also do research on The Effect of Compensation on Employee Performance with Motivation as an Intervening Variableand the results obtained that compensation has a significant effect on performance. In addition, research results from 
Umar (2010) who examined the effect of compensation on performance resulted in a significant influence between compensation on performance. Research on compensation variables has been done a lot so that researchers want to find out whether additional compensation given to Financial Administration Officers (PPK) is deemed appropriate and will affect the performance of Financial Administration Officers (PPK) in completing SKPD Financial Statements which are their duties.Another determinant of performance factors is competence.

According to Wibowo (2007) states that competence is the ability to carry out or perform a job or task which is based on skills and knowledge and is supported by the work attitude demanded by the job.The financial reports themselves should be prepared by an accountant, while in the Pasuruan City Government the SKPD financial reports are prepared by Financial Administration Officers (PPK) whose educational background is not necessarily from the accounting department. In preparing financial reports, a Financial Administration Officer (PPK) is expected to be able to understand the government accounting system, whereas in fact many Financial Administration Officers (PPK) do not have an accounting background. This makes researchers want to research the effect of competence on performance, which is an important variable in improving performance.

The importance of competence in influencing performance according to research conducted by Sriekaningsih and Setyadi (2015) and the result is that competence has a significant effect on performance. The opposite research results were generated by the research conducted by Meutia et al. (2016) where competence has no effect on performance.

Apart from compensation and competence, the motivation variable is a variable that affects performance. Weiner (1990) motivation is an internal condition within a person that can arouse someone to take an action, motivation can encourage someone to achieve certain goals besides motivation can make individuals interested in carrying out certain activities. Motivation is a factor that can encourage an individual to get work done. With high motivation someone will be able to do their job well. Motivation is a variable that can directly affect employee performance as well as an intervening variable that affects compensation and competence on performance.

Research on The influence of motivation directly on performance and motivation as a link for other variables on performance has been widely carried out, such as research conducted by Meutia et al. (2016) who examined the effect of compensation and competence with motivation as an intervening variable in improving performance where the results of the study indicated that motivation had a significant effect on performance. 
The purpose of this paper is to analyze and prove directly the effect of compensation, competence and motivation on performance. As well as, analyzing and indirectly proving motivational variables as mediation that have to do with compensation, competency, and performance variables.

\section{THEORETICAL REVIEW}

\section{Compensation}

Compensation is everything that employees receive in return for their work (Sedarmayanti, 2011). Compensation is a contra-performance against the use of labor or services that have been provided by the workforce to the company (Wibowo, 2007).The purpose of the company to provide compensation to its employees is a partnership between the company and its employees; Provide job satisfaction to employees; Provide opportunities for the procurement / recruitment process for qualified employees; Provide motivation to employees; Provide stability to employees; Foster a sense of employee discipline; Minimizing trade union influence; Compliance with government regulations (Hasibuan, 2002). Research on the effect of compensation on motivation was conducted by Meutia et al. (2016), Dito (2010) and Negash et al. (2014). While research on the influence of competence on motivation was conducted by Rahman et al (2014) and Rinawati et al. (2014).

H1: It is suspected that high compensation will increase the motivation of the Financial Management Officer

The results of research meutia et al. (2016), Dito (2010), Andriana (2017), Uju (2013) and Umar (2010) showed that there was a significant influence of compensation variables on performance.

H3 : high compensation will increase will improve the performance of the Financial Management Officer

\section{Competence}

UU no. 13 of 2003 Regarding Manpower, it is stated that competence is the work ability of each individual which includes aspects of knowledge, skills, and work attitudes in accordance with established standards. that competence is the ability to carry out or perform a job or task which is based on skills and knowledge and is supported by the work attitude demanded by the job (Wibowo, 2007). Competence is an ability that a person has in completing a task or job, where this ability is influenced by two factors, namely intellectual and physical (Robbins, 2007). This is reinforced by the results of research Meutia et al. (2016), Dito (2010), Andriana (2017), Uju (2013) and Umar (2010) which showed that there is a significant influence of compensation variables. 
$\mathrm{H} 2$ performance: It is suspected that adequate competence will increase the motivation of the Financial Management Officer.

The results of research from Sriekaningsih et al. (2015) and Rinawati et al.(2014) stated that competence has a significant influence on employee performance.

$\mathrm{H} 4$ : It is suspected that adequate competence will improve the performance of the Financial Management Officer in the completion of the Pasuruan City Regional Financial Report

\section{Motivation}

Motivation is a process that takes into account the individual's intensity, direction, and persistence of efforts to achieve a goal (Robbins and Judge, 2013). Luthan (2011) explains that motivation is a process that begins with a physiological or psychological deficiency or a need or motive that activates goal-directed behavior or incentives. Thus, the key to understanding the motivational process lies in the meaning of the relationships among motives, needs, behaviors, and incentives.

Many studies on the influence of motivation on performance have been conducted, namely research conducted by Meutia et al. (2016), Rahman et al. (2014), Dito (2010), Rinawati et al. (2014), Shahzadi, et al. (2014) and Sriekaningsih et al. (2015) which states that motivation affects performance.

H5: Allegedly Strong Motivation will improve the performance of The Financial Management Officer in the completion of the Pasuruan City Regional Financial Report.

\section{Performance}

Performance is the result of the implementation of a job, whether physical / material or non-physical or non-physical / non-material (Nawawi, 2011). While Rivai et al. (2015) explaining that performance is a function of motivation and ability so that in completing a task or job a person should have a certain degree of willingness and level of ability.

The research was also strengthened by the results of research conducted by Andriana (2017) which showed the effect of compensation on the performance of employees of PT Iskandar Indah Printing. From the results of the study, researchers formulated hypothesis 6 (H6) as follows:

H6: Allegedly high compensation will improve the performance of the Financial Management Officer in the completion of the Pasuruan City Regional Financial Report through motivation as an intervening variable.

The research was strengthened by the results of research from Rinawati et al. (2014) which stated that competence affects employee performance with Motivation as an 
intervening variable in the Non Vertical Unit (SNVT) of the Ministry of Public Works in Semarang. From the results of the study, researchers formulated hypothesis $7\left(\mathrm{H}_{7}\right)$ as follows:

H7: Allegedly high competence will improve the performance of The Financial Management Officer in the completion of the Pasuruan City Regional Financial Report through motivation as an intervening variable.

\section{METHODOLOGY}

This research approach uses quantitative verification analysis (Now, 2006). The type of research used in the writing of this thesis is explanatory research or explanatory research (Singarimbun, 2009). The population and sample of this research are 33 Financial Administration Officers (PPK), so the sample used is saturated sample (Sugiyono, 2015). Collecting data using a questionnaire with a Likert scale. The operational definition in this research includes compensation (Simamora, 2004), competence (Wibowo, 2007), motivation (Amabile, et al., 1994), and employee performance (Mas'ud, 2004). Data analysis using SEM-PLS.

\section{RESEARCH RESULTS}

\section{Profile Informants}

Based on the characteristics of the respondents, it is known that Financial Administration Officers (PPK) in terms of gender are dominated by women as much as $72.73 \%$, with a vulnerable age of $41-50$ years as much as $51.52 \%$, those with an undergraduate education (66.67\%), and the length of work is over 20 years ( $39.39 \%$ )

\section{Outer Model - Goodness of Fit}

The test results if the loading factor value is above 0.7 , it is said to be ideal and valid. However, a loading factor value above 0.5 is also acceptable, but if the loading factor value is below 0.5 , the item used must be removed from the model. In this study, a critical value of 0.6 was used.

Based on the cross loading value, it can be seen that all the indicators that make up each variable in Figure 1 have met discriminant validity because it has the largest outer loading value for the variables it forms and not the other variables.

The AVE value for the four constructs is greater than 0.5 , so it can be concluded that the evaluation of the measurement model has good discriminant validity. In addition to the construct validity test, the construct reliability test was also carried out as measured by the criteria test, namely composite reliability and Cronbach alpha from the indicator block measuring the construct. The construct is declared reliable if the composite reliability and Cronbach alpha values are above 0.70 . So it can be concluded that the construct has good reliability. 


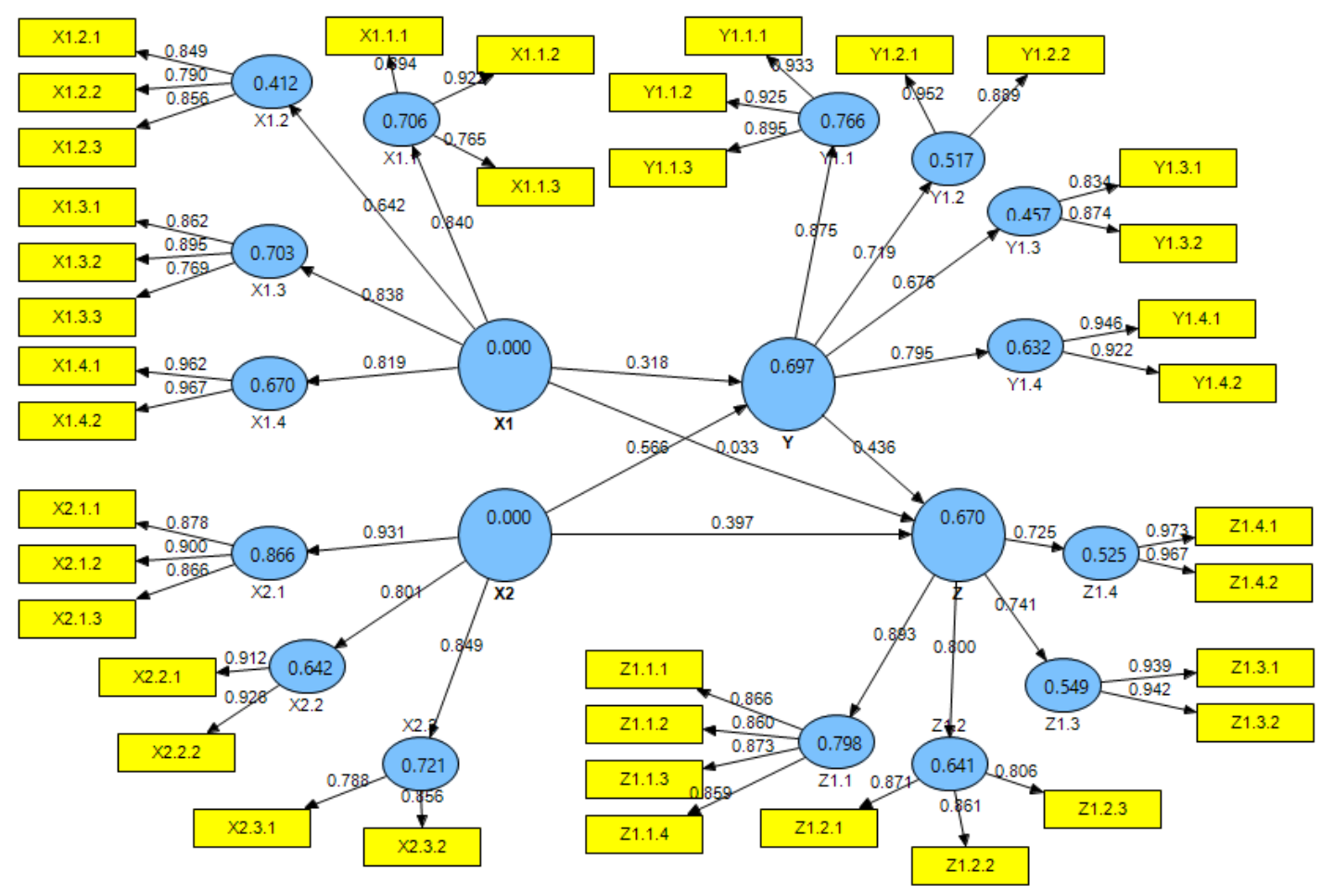

Figure 1. Structural Model (Outer Model)

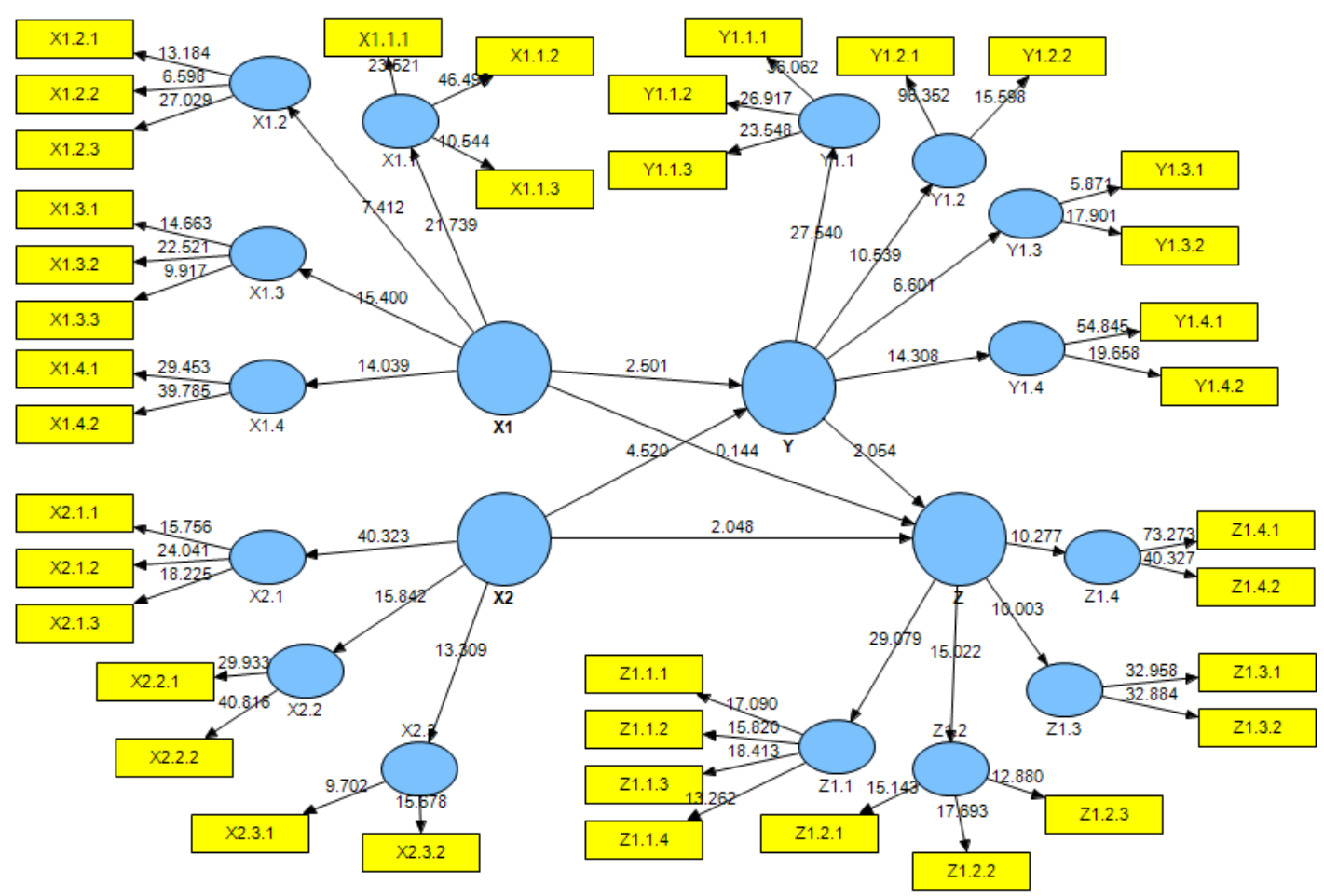

Figure 2. Structural Model (Inner Model) 
The R-square value for the motivation variable is 0.6972 . The R-square value shows that $69.72 \%$ of the Motivation ( $\mathrm{Z}$ ) variable can be influenced by the Compensation variable, Competence. while the remaining $30.28 \%$ is influenced by other variables outside the one under study. Meanwhile, the R-square value of Performance is 0.6695 , indicating that the variable Performance $(\mathrm{Y})$ is influenced by the Compensation, Competence, and Motivation ( $Z$ ) variable of $66.95 \%$, while the remaining $33.05 \%$ is influenced by other variables outside the one under study.

The Q2 value is 0.8999 , meaning that the amount of data diversity from the study that can be explained by the structural model designed is $89.99 \%$, while the remaining $10.01 \%$ is explained by other factors outside the model. Based on these results, it can be said that the structural model in this study is quite good because it is closer to the value of 1.

\section{Research Hypothesis Testing}

Bootstrapping testing is also intended to minimize the problem of abnormal research data. The test results with bootstrapping from the PLS analysis are as follows:

Table 1. Hypothesis Testing Results

\begin{tabular}{ccccc}
\hline $\begin{array}{c}\text { Variable } \\
\text { Relationships }\end{array}$ & $\begin{array}{c}\text { Estimation } \\
\text { Coefficient }\end{array}$ & $\begin{array}{c}\text { Standard } \\
\text { Deviation }\end{array}$ & $\begin{array}{c}\text { Don't } \\
\text { count }\end{array}$ & $\begin{array}{c}\text { p- } \\
\text { value }\end{array}$ \\
\hline X1 $>$ Y & 0.318 & 0.127 & 2.501 & 0.018 \\
X $->$ Y & 0.566 & 0.125 & 4.520 & 0.000 \\
X1 $>$ Z & 0.033 & 0.226 & 0.144 & 0.886 \\
X $->$ Z & 0.397 & 0.194 & 2.048 & 0.048 \\
Y $>$ Z & 0.436 & 0.212 & 2.054 & 0.048 \\
\hline
\end{tabular}

The calculation of the amount of the indirect effect and the relationship between variables using the Sobel formula has been presented in a summary of the results. The summary is seen in Table 2 .

Table 2. Indirect Effects

\begin{tabular}{lcccccccc}
\hline \multirow{2}{*}{ Variable } & \multicolumn{2}{c}{ Direct Coefficient } & \multicolumn{2}{c}{ standard error } & Coefficient & se & t Count & P-Value \\
& $X \rightarrow Y$ & $Y \rightarrow Z$ & $X \rightarrow Y$ & $Y \rightarrow Z$ & Indirect & Sobel & & \\
\hline$X_{1} \rightarrow Y \rightarrow Z$ & 0.318 & 0.436 & 0.127 & 0.212 & 0.138 & 0.104 & 1.327 & 0.194 \\
$X 2 \rightarrow Y \rightarrow Z$ & 0.566 & 0.436 & 0.125 & 0.212 & 0.247 & 0.119 & 2.065 & 0.048 \\
\hline
\end{tabular}

\section{DISCUSSION}

\section{Determinants of Compensation and Motivation}

In terms of hypothesis testing, it is known that compensation is able to motivate in increasing the motivation of Financial Administration Officials (PPK). These results are in 
accordance with the research results Meutia et al. (2016) and Dito (2010), which states that compensation is one of the factors that increase motivation. The employee will be motivated to put a large amount of effort into his work if he feels that his previous efforts have resulted in the reward or award he has received (John and Smith, 2014). Compensation in the form of salary, performance bonus, recognition and praise is a management tool that can be used to motivate employees to perform effectively and efficiently. Each award must adequately satisfy a basic need, be considered fair, individually oriented (Van Der Aalst et al., 2003). By providing appropriate compensation will provide motivation within a person. For example, by providing a decent salary I wage and in accordance with existing regulations, employees will feel valued and their needs are met so that this can encourage employee motivation to work. In the Pasuruan City Government, all Civil Servants (PNS) including Financial Administration Officers (PPK) have been given salaries, allowances, incentives and facilities in accordance with existing regulations. Salaries are given according to class, allowances are given in accordance with applicable regulations such as child, wife, health insurance benefits, incentives are given in the form of additional employee income while facilities are given according to applicable regulations such as official motorbikes, official cars, laptops, computers.

\section{Determinant Competence and Motivation}

In terms of hypothesis testing, it is known that competence is able to motivate in increasing the motivation of Financial Administration Officials (PPK). These results are in accordance with the research results Rahman et al (2014) and Rinawati et al. (2014) which states that competence is one of the factors that increase motivation. Improving employee performance can be done by increasing employee competence (Wibowo, 2007). Competence is very important in increasing motivation, with adequate competence in terms of knowledge, skills or ability in attitude will be able to motivate someone. Boyatzis (1982) stated that for various industries, competence is believed to be an enabling factor (enabler) of an organization to build its competitive advantage by providing a framework for human resource functions to be directed sharply at activities to build the capabilities of its employees. In the Pasuruan City Government, the competency improvement of Financial Administration Officers (PPK) related to the preparation of financial reports continues to be carried out in various ways such as regular technical guidance, socialization related to changes in rules or by providing assistance in preparing financial reports.

\section{Determinant Compensation and Employee Performance}

Simamora (2004) noted that there are two key considerations in an effective compensation system. First, the compensation system must be situation-adaptive, the system must be appropriate to the environment and consider objectives, resources, and organizational structure. Second, the compensation system must motivate employees. 
The system must be able to satisfy employee needs, ensure fair treatment of employees, and reward performance. By providing appropriate compensation in the form of wages / salaries, incentives, allowances and facilities from the company, it is hoped that it can encourage someone to work so that the employee's performance can increase. The compensation given is expected to improve employee performance in carrying out their duties and obligations within the company. From the description above shows that compensation is a very important factor that can improve employee performance and it is fitting that companies can use compensation as a solution in improving employee performance. However, in testing the research hypothesis, it is known that compensation has an insignificant effect in improving the performance of the Financial Administration Officer (PPK). These results contradict the results of the study However, in testing the research hypothesis, it is known that compensation has an insignificant effect in improving the performance of the Financial Administration Officer (PPK). These results contradict the results of the study However, in testing the research hypothesis, it is known that compensation has an insignificant effect in improving the performance of the Financial Administration Officer (PPK). These results contradict the results of the study Meutia et al. (2016), Dito (2010), Andriana (2017), Umar (2010) and Negash et al. (2014) which indicates that there is a significant effect of the compensation variable on performance. This is very possible because compensation for Financial Administration Officers who are Civil Servants in the form of wages, salaries, incentives, allowances and facilities has been regulated by clear rules so that the compensation received will have an effect but the effect will not have much impact on the performance of the Financial Administration Officer. (PPK) in completing Financial Statements. The amount of compensation received by the Financial Administration Officer (PPK) is deemed to be in accordance with the workload carried out so that the amount of compensation is considered to affect the performance of the Financial Administration Officer (PPK) but has no significant effect,

\section{Determinant Competence and Employee Performance}

In terms of hypothesis testing, it is known that competence can improve the performance of Financial Administration Officers (PPK). These results are in accordance with the research results Wibowo (2007) states that competence and work culture can affect employee performance. This is reinforced by the results of research from Sriekaningsih et al. (2015), Rahman et al. (2014), Rinawati et al. (2014) which states that competence has a significant effect on employee performance.

Competence can affect employee performance (Wibowo, 2007). Competence is said to be one of the factors that affect performance (Borjas, 1979). Competence is needed to help organizations to create a high performance culture. The number of competencies used by human resources will improve performance. Competence supports employees to be able to improve their performance (Wibowo, 2007). Having competent human resources can improve performance according to the targets set by the company. 
Employee competency improvement can be carried out in various ways, namely through training, education and training, seminars etc.

In the Pasuruan City Government, the competency improvement of Financial Administration Officers (PPK) related to the preparation of financial reports continues to be carried out in various ways such as regular technical guidance, socialization related to changes in rules or by providing assistance in preparing financial reports. The results show that the increased competence carried out by the Pasuruan City Government so far has improved the performance of Financial Administration Officers in completing financial reports. This means that the more competency of the Financial Administration Officers are increased, the performance of the Financial Administration Officers in completing financial reports will increase.

\section{Determinant Motivation and Employee Performance}

In terms of hypothesis testing, it is known that motivation can improve the performance of the Financial Administration Officer (PPK). These results are in accordance with the research results Meutia et al. (2016), Rahman et al. (2014), Dito (2010), Andriana (2017), Rinawati et al. (2014), Uju (2013), Shahzadi, et al. (2014), Sriekaningsih et al. (2015) which states that competence has an effect on performance.

Motivation really supports employee performance such as productivity and persistence. Employees will be more responsible if offered opportunities to develop (Gungor, 2011). Motivated employees are also more willing to be involved in the work of their colleagues, when compared to employees who are not motivated (Kuvaas and Dysoik, 2009). Someone wants to work because there is an individual need so that employees are motivated, the company must help employees achieve their individual goals, one of which is by meeting the employee's needs. According to Van Der Aalst et al., (2004) states that Praise and recognition are the most efficient intrinsic rewards that increase employee performance. Intrinsic reward is a tool to motivate employees to work as expected. Motivation is very important in improving performance because it is motivation that will encourage individuals to do a job. Motivation can determine the speed of a person's work. Motivated employees will be more motivated to immediately complete their work as well as possible. In the Pasuruan City Government, many things have been done to increase the motivation of Financial Administration Officers (PPK) such as additional income in the form of other objective considerations on the Additional Employee Income (TPP) component as well as various education and training, technical guidance or socialization that have been carried out a lot. This is done to motivate Financial Administration Officers (PPK) in completing financial reports. This is in accordance with the results of hypothesis testing where the increase in motivation of Financial Administration Officers (PPK) can improve performance in completing financial reports. This means that if the Pasuruan City Government always increases the motivation of the Financial Administration Officers (PPK), the completion of financial 
reports will be even better. From the description above shows that motivation is a very important factor that can improve employee performance and should always increase employee motivation because increasing employee motivation can improve employee performance.

\section{Determinant Competence, Motivation, Employee Performance}

Hasibuan (2002) states that one of the goals of compensation is motivation. By providing appropriate compensation, it is hoped that it will motivate employees to complete their work. A motivational boost is very important because with the emergence of motivation it will encourage someone to do the work assigned to him more quickly and precisely. If the remuneration provided is large enough, managers will easily motivate their subordinates. Motivation is a process that plays a role in the intensity, direction, and duration of individual efforts towards achieving goals (Robbins, 2007). So that if an employee considers that the compensation provided by the company is as expected, it will be able to motivate employees to improve their performance.

In terms of hypothesis testing, it is known that motivation has an insignificant influence in bridging compensation to the performance of Financial Administration Officers (PPK). These results contradict the results research by Meutia et al. (2016), Dito (2010) and Andriana (2017) which states that compensation has an effect on performance through motivation variables. This is very possible because compensation for Financial Administration Officers (PPK) who are Civil Servants in the form of wages, salaries, incentives, allowances and facilities has been regulated by clear rules so that the compensation received affects the performance of Financial Administration Officers (PPK) but insignificant on the performance to complete financial statements through motivation as an intermediary. The amount of compensation received by the Financial Administration Officer (PPK) is deemed to be in accordance with the workload carried out so that the amount of compensation is considered to have little effect on the performance of the Financial Administration Officer (PPK) through motivation as an intermediary.

\section{Determinant Competence, Motivation, and Employee Performance}

In terms of hypothesis testing, it is known that motivation is able to bridge competencies to the performance of Financial Administration Officers (PPK) in completing financial reports. These results are in accordance with the results of research Rahman et al. (2014) and Rinawati et al. (2014) which states that competence affects performance through motivation variables.

Employee competence is a manifestation of all forms of ability they have. Employees will be motivated if their competencies are as expected by the company. This competence will have an impact on the level of self-confidence in work. Highly competent employees will tend to show their abilities through their achievements in the company. Motivation 
is very supportive of employee performance such as productivity and persistence (Gungor, 2011). With high competence and in accordance with what the company needs, it will motivate these employees so that they can improve their performance. Competence is very important in increasing motivation, with adequate competence both knowledge, skills or ability to behave will be able to grow someone's motivation. If someone is motivated, they will be able to improve their performance because it is motivation that will encourage individuals to do a job.

In the Pasuruan City Government, the competency improvement of Financial Administration Officers (PPK) related to the preparation of financial reports continues to be carried out in various ways such as regular technical guidance, socialization related to changes in rules or by providing assistance in preparing financial reports. With the increased motivation of Financial Administration Officers (PPK), it is hoped that it can improve the performance of Financial Administration Officers (PPK) in completing financial reports. The results of the research show that the increased competence carried out by the Pasuruan City Government so far has greatly motivated the Financial Administration Officers so that in the end they increased their performance in completing financial reports. This means that the more frequent competency of Financial Administration Officers are increased, it will increase the enthusiasm of Financial Administration Officers and in the end it can improve their performance in completing Financial Statements. This proves that increasing employee competence can be a solution in increasing employee motivation which in turn can improve employee performance.

\section{CONCLUSION}

From the above discussion, it can be concluded that compensation is able to increase motivation. However, it has not been able to improve performance. Furthermore, competence can increase motivation and be able to improve performance. On the other hand, motivation can improve performanceFinancial Administration Officer. Other results, indirectly it is known that motivation has not been able to mediate the relationship between compensation and performance. In addition, motivation is able to mediate the relationship between competence and the performance of the Financial Administration Officer.

Given that the independent variables in this study are very important in influencing performance, it is expected that the results of this study can be used as a reference for further researchers to develop this research by considering other variables which are other variables outside the variables that have been included in this study. 


\section{REFERENCES}

UU no. 13 of 2003 concerning Manpower

Government Regulation Number 71 of 2010 concerning Government Accounting Standards

Amabile, T., Hill, KG, Hennessey, BA, \& Tighe, EM (1994). The Work Preference Inventory: Assessing Intrinsic and Extrinsic Motivational Orientations. Journal of Personality and Social Psychology, 66(5), 950-967.

Andriana. (2017). Effect of Compensation on Employee Performance with Motivation as an Intervening Variable. Management Journal.

Borjas G. (1979) Job satisfaction, wages and unions. Journal of Human Resources, XIV, . 21-40.

Boyatzis R. (1982). The competent manager: a model for effective performance. New York: Wiley \& Sons.

Dito. (2010). Effect of Compensation on Employee Performance of PT. Slamet Langgeng Purbalingga with Work Motivation as an Intervening Variable. Management Journal

Gungor, P. (2011) The Relationship Between Reward Management System and Employee Performance with the mediating Role of Motivation: A Quantitative Study on Global Bankss. Procedia Social and Behavioral Science, 24, 1510-1520.

Hasibuan, Malayu SP (2009). Basic Management, Understanding, and Problems. Jakarta: Earth Literacy.

Hasibuan, Malayu SP. (2006). Human Resource Management. Jakarta: PT. Haji Masagung.

John, R. and Smith, A. (2014). Awareness and effectiveness of quality function deployment (QFD) in design and build projects in Nigeria. Journal of Facilities Management, 12 (1), 72-88.

Kuvaas, B., \& Dysvik, A. (2009). Perceived investment in employee development, intrinsic motivation and work performance. Human resource management journal, 19 (3), 217-236.

Luthans, F. (2011). Organizational behavior: an evidence-based approach (12.ed.) Boston, McGraw-Hill.

Mas'ud, F. (2004). Organizational Diagnostic Survey. Semarang; Diponegoro University Publishing Agency. 
Mathis, RL, \& Jackson, J. (2011). Human Resource Management: Essential Perspectives. Cengage Learning.

Meutia, Sari, Ismail. (2016). The Effect of Compensation and Compensation with Motivation as Intervening in Improving Performance. Management Journal, XX(3), 353-369

Nawawi, (2011). Human Resource Management: For Competitive Business. Gajahmada University Press, Yogyakarta.

Negash, Zewude, Megersa. (2014).The effect of compensation on employees motivation in Jimma University academic staff. Basic Research Journal of Business Management and Accounts

Rahman, Lely, Soleh. (2014). The Effect of Competence and Leadership on Employee Performance with Motivation as an Intervening Variable. Management Journal.

Rinawati, Ingsih. (2014). The Effect of Work Environment and Competence on Employee Performance with Motivation as an Intervening Variable in Certain Non-Vertical Work Units (Snvt) of the Ministry of Public Works in Semarang. Journal of Management.

Rivai, Ramly, Mutis and Arafah. (2015). Human Resource Management for Companies: From Theory to Practice. PT. Raja Grafindo Persada, Jakarta.

Robbins, SP and Judge, TA (2013). Organization Behavior (15th Edition). PEARSON.

Robbins, Stephen P. (2007). Organizational Behavior. Bandung: PT Index.

Sedarmayanti. (2011). Human Resource Management, Bureaucratic Reform and Civil Servant Management. Bandung: PT RefikaAditama.

Now, Uma. (2006). Research Methods For Business. Edition 4. Jakarta: Four Salemba.

Shahzadi, Javed, Pirzada, Nasreen, Khanam. (2010). Impact of Employee Motivation on Employee Performance. European Journal of Business and Management.

Simamora, Henry. (2004). Human Resource Management. Yogyakarta: STIE YKPN.

Singarimbun, Masri \& Effendi Sofian. (2009). Survey Research Methods. Jakarta: LP3ES.

Sriekaningsih, Setyadi. (2015).The Effect of Competence and Motivation and Cultural Organization towards Organizational Commitment and Performance on State University Lecturers in East Kalimantan, Indonesia. European Journal of Business and Management. 
Sugiyono. (2015). Quantitative Qualitative Research Methods R\&B. Bandung: Aflabeta.

Uju. (2013).The Influence of Motivation on Employees' Performance: A Study of Some Selected Firms in Anambra State.Journal of Arts and Humanities Bahir Dar, Ethiopia.

Umar. (2010).The Influence of Compensation on Performance of Sales Representatives of Pharmaceutical Companies Based in Ilorin-Nigeria. An International MultiDisciplinary Journal, Ethiopia.

Van Der Aalst, W., Van Hee, KM, \& van Hee, K. (2004). Workflow management: models, methods, and systems. MIT press.

Weiner, B. (1990). History Of Motivational Research In Education. Journal Of Educational Psyhology. 82 (4)

Wibowo. (2007). Work management. Jakarta: Rajawali Pres. 